\title{
Trade variety and political conflict: Some international evidence
}

\author{
Yothin Jinjarak * \\ Division of Economics, School of Humanities, Arts, and Social Sciences, Nanyang Technological University (NTU), S3-B2A-06, Singapore 639798, Singapore
}

\section{A R T I C L E I N F O}

\section{Article history:}

Received 24 February 2008

Received in revised form 8 January 2009

Accepted 12 January 2009

Available online 22 January 2009

\section{Keywords:}

Globalization

Imports

Networks

Politics

Variety

JEL classification:

F10

F50

$\mathrm{O} 20$

\begin{abstract}
A B S T R A C T
Growth in imported product variety is associated with lower internal, external, and overall political conflicts. Differentiated products, reference priced products, and organized exchange products display similar variety effects. The significance of conflict-reducing gains from variety is larger for poorer countries.
\end{abstract}

(c) 2009 Elsevier B.V. All rights reserved.

\section{Overview}

Does trade improve lives? To the public, one dramatic explanation for improved living standards is the decline in deaths from violence and genocide, and in the number of wars and political conflicts (Economist, 2008). This paper takes the growth of trade variety as an integral part of the globalization process, and examines its association with the level of internal and external political conflicts across countries. The results from panel data estimation suggests that there are conflict-reducing gains from variety growth.

Following Broda and Weinstein (2004), trade variety is measured by the average number of importing sources per imported product. A panel data on imports of 134 countries are taken from the NBERUnited Nations Trade Data 1962-2000. This data cover 433 product categories at 4-digit Standard International Trade Classification (SITC). Because the SITC classification went through a major change in 1983 , the present sample starts from 1984 onwards. The measures of political conflict are extracted from the international political risk scores, compiled by International Country Risk Guide (ICRG). The ICRG reports for each country a composite political risk indicator, which is a

\footnotetext{
is The author would like to thank an anonymous referee, Ho Kong Weng, Euston Quah, Brendan Quigley, and seminar participants at Chulalongkorn University for comments and suggestions. Financial support from the School of Humanities, Arts, and Social Sciences at NTU is gratefully acknowledged.

* Tel.: +65 6790 6798; fax: +65 67946303 .

E-mail address: yjinjarak@ntu.edu.sg.
}

combination of scores on internal conflicts, external conflicts, corruption, bureaucratic quality, democratic accountability, ethnic tensions, government stability, law and order, military in politics, and religious tensions. The paper focuses on the internal and the external conflict components, taking the composite risk score as a proxy for a country's overall political conflict level. Another possible measure is the number of casualties of wars, ${ }^{1}$ but using it will underestimate the extent of internal and external political conflicts.

Fig. 1 plots the average numbers of imported product variety and the average scores on political conflict (higher score $=$ more conflicts) across countries by their income groups. ${ }^{2}$ From 1985 to 2000, a percentage increase in trade variety of the high-income, the uppermiddle income, the lower-middle income, and the low-income countries are 53,68,51, and 31, respectively. These groups of countries also witness their exposure to political conflicts fall by $7,9,7$, and $5 \%$, respectively. For the middle-income and the low-income countries, the internal conflicts dropped by $10 \%$ and the external conflicts by $30 \%$. Controlling for a time trend, could the growth of trade variety contribute to the observed world-wide reduction in the level of political conflicts?

\footnotetext{
${ }^{1}$ International Peace Research Institute (Oslo) provides the statistics online at www. prio.no.

2 World Bank's per capita income classification.
} 


\section{Estimation}

Let $i$ denotes country and $t$ time period. The regression equation is

$$
\begin{aligned}
\text { Conflict }_{t}^{i}= & \alpha \text { Conflict }_{t-1}^{i}+\beta \text { Variety Growth } \\
& +\theta^{\prime}\left[\text { Variety Growth }_{t-1}^{i} \times \text { Income }^{i}\right]+t+\lambda_{t}+\eta^{i}+\varepsilon_{t}^{i}
\end{aligned}
$$

The specification (1) takes into account the effects of past political conflicts, a time trend $(t)$, a time fixed effect $\left(\lambda_{t}\right)$ and a country fixed effect $\left(\eta^{i}\right)$, with $\varepsilon_{t}^{i}$ as an error term. All variables are in logs so their coefficient estimates have a direct elasticity interpretation. To allow for different slopes across the high-income, the middle-income, and the low-income country groups, the estimation also includes the interaction between Variety Growth and Income group dummy variables.

Table 1 reports the results from LSDV fixed effects, GMM dynamic panel (Arellano and Bond, 1991), and the dynamic panel with 5-year average variety growth. The average number of years per country is 12 so the dynamic panel is the most appropriate (Judson and Owen, 1999). Lagged political conflict has a positive effect on the current one as expected. Based on the $R^{2}$ of the LSDV fixed effects, this econometric specification is able to explain around $70 \%$ of political conflicts across countries during the sample period. Variety Growth is negatively associated with the internal, the external, and the overall political conflicts. The effects of variety growth are non-linear: coefficient estimates of the Variety Growth × Income interaction terms are positive and larger for lower income groups. This does not necessarily mean the effect of variety growth is a decreasing function of income: its economic significance will vary with its standard deviation across the income groups.
Table 1

\begin{tabular}{|c|c|c|c|c|c|c|}
\hline \multirow[t]{2}{*}{ Political conflict } & \multicolumn{2}{|c|}{ Internal conflict } & \multicolumn{2}{|c|}{ External conflict } & \multicolumn{2}{|c|}{ Overall conflict } \\
\hline & Beta & [S.e.] & Beta & [S.e.] & Beta & [S.e.] \\
\hline \multicolumn{7}{|c|}{$(134$ countries; average years per country $=12$ ) } \\
\hline \multicolumn{7}{|c|}{ LSDV fixed-effects } \\
\hline Lagged conflict & 0.83 & $(0.01)^{* * *}$ & 0.80 & $(0.02)^{* * *}$ & 0.81 & $(0.01)^{* * *}$ \\
\hline Variety growth & -0.42 & $(0.12)^{* * *}$ & -0.31 & $(0.14)^{* *}$ & -0.15 & $(0.05)^{* * *}$ \\
\hline$\times$ Middle income & 0.29 & $(0.15)^{*}$ & 0.08 & $(0.18)$ & 0.03 & $(0.06)$ \\
\hline$\times$ Low income & 0.42 & $(0.17)^{* *}$ & 0.35 & $(0.20)^{*}$ & 0.01 & $(0.07)$ \\
\hline$R^{2}$ & 0.70 & & 0.67 & & 0.78 & \\
\hline \multicolumn{7}{|c|}{ GMM dynamic panel using annual variety growth } \\
\hline Lagged conflict & 0.91 & $(0.02)^{* * *}$ & 0.93 & $(0.02) * * *$ & 0.76 & $(0.02)^{* * *}$ \\
\hline Variety growth & -0.52 & $(0.12)^{* * *}$ & -0.35 & $(0.15)^{* *}$ & -0.13 & $(0.05)^{* * *}$ \\
\hline$\times$ Middle income & 0.40 & $(0.16)^{* *}$ & 0.36 & $(0.20)^{*}$ & 0.03 & $(0.06)$ \\
\hline$\times$ Low income & 0.60 & $(0.17)^{* * *}$ & 0.46 & $(0.22)^{* *}$ & 0.02 & $(0.07)$ \\
\hline \multicolumn{7}{|c|}{ GMM dynamic panel using 5-year average variety growth } \\
\hline Lagged conflict & 0.85 & $(0.02)^{* * *}$ & 0.93 & $(0.02)^{* * *}$ & 0.74 & $(0.02)^{* * *}$ \\
\hline Variety growth & -2.15 & $(0.38)^{* * *}$ & -1.07 & $(0.48)^{* *}$ & -0.26 & $(0.15)^{*}$ \\
\hline × Middle income & -0.23 & $(0.52)$ & 1.10 & $(0.64)^{*}$ & -0.36 & $(0.21)^{*}$ \\
\hline$\times$ Low income & 1.22 & $(0.62)^{* *}$ & 0.97 & $(0.80)$ & -0.06 & $(0.24)$ \\
\hline
\end{tabular}

Baseline estimation

Variables are in logs. The regression equation is Conflict $_{t}^{i}+\alpha$ Conflict $_{t-1}^{i}+\beta$ Variety Growth $_{t-1}^{i}+\theta^{\prime}$ [Variety Growth ${ }_{t-1}^{i} \times$ Income $\left.^{i}\right]+t+\lambda_{t}+\eta^{i}+\varepsilon_{t}^{i}$.

The estimation also includes a constant and a time trend (coefficients not reported). Standard errors are in parentheses. $* * *, * *, *$ signifies statistically significance at 1,5 , and $10 \%$ level, respectively.

Eq. (1) is then estimated with the variety growth of three broad product categories according to Rauch (1999)'s classification: differentiated products $(n)$, reference priced products $(r)$, and organized exchange products $(w)$. The correlations between the aggregate variety growth and that of $n, r, w$ are $0.69,0.61,0.43$, respectively.

Dark color: differentiated products ( $n$ ), Gray: reference priced products (r); White: organized exchange products (w)
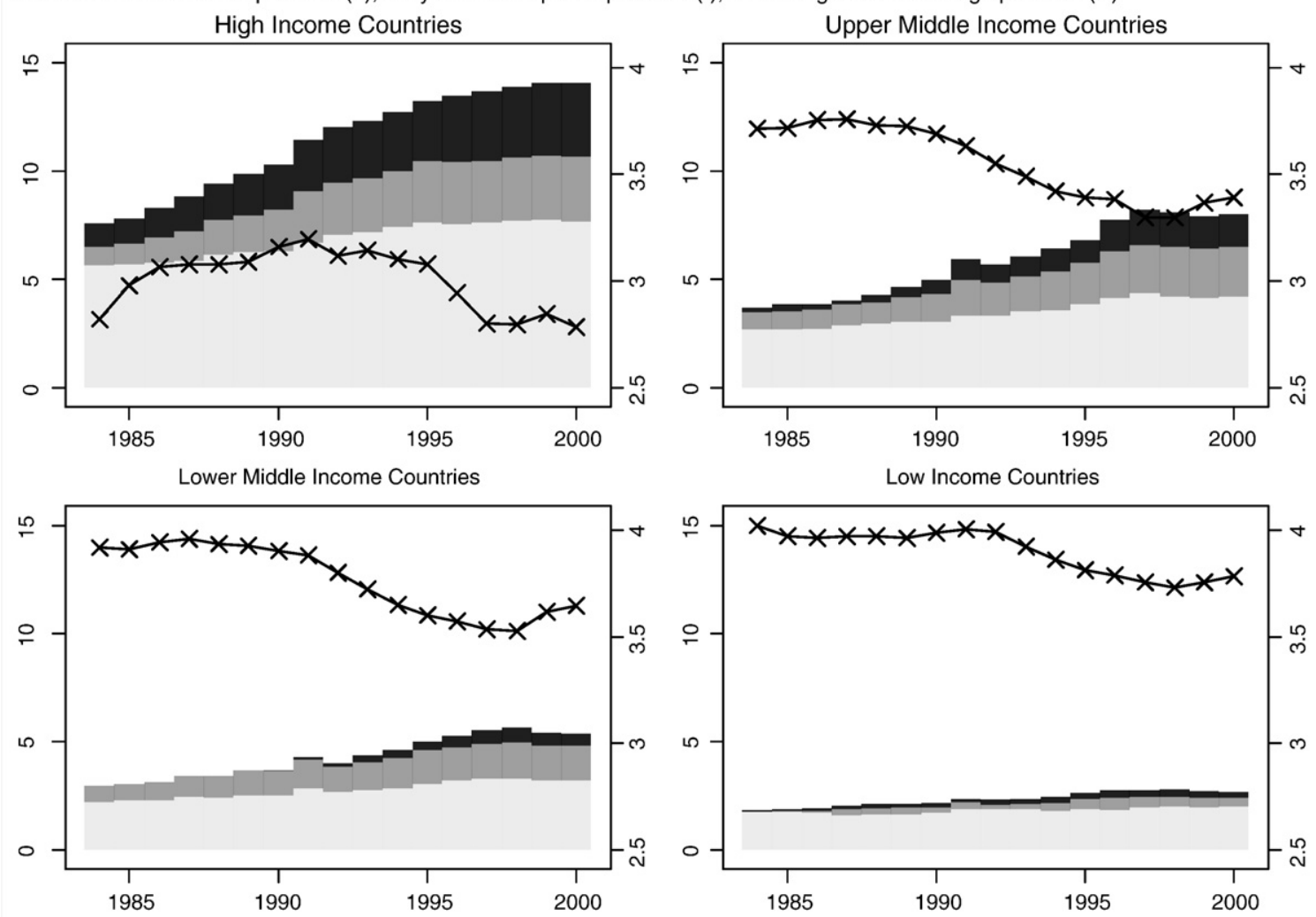

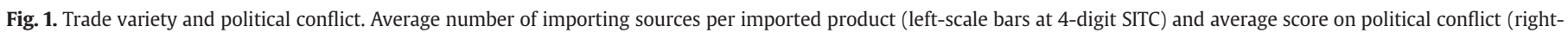
scale lines in logs, higher ICRG score = more conflicts). 
Table 2

Economic significance

\begin{tabular}{llll}
\hline Political conflict & \multicolumn{3}{l}{ Conflict-reducing effect (\%) by income group } \\
\cline { 2 - 4 } & Trade variety & Middle-income & Low-income \\
\hline Internal & $n$ & -5.1 & -10.5 \\
& $r$ & -5.1 & -10.1 \\
External & $w$ & -3.7 & -8.4 \\
& $n$ & -1.4 & -2.7 \\
\multirow{3}{*}{ Overall } & $r$ & -1.2 & -4.0 \\
& $w$ & -1.0 & -7.6 \\
& $n$ & -.9 & -2.1 \\
& $r$ & -1.1 & -2.4 \\
\hline
\end{tabular}

$n$ : differentiated products; $r$ : reference priced products; $w$ : organized exchange products. For each trade variety and income group, the conflict-reducing effect of variety growth is calculated by multiplying a 1-standard deviation increase of the variety growth with its coefficient estimate from the GMM dynamic panel using 5-year average variety growth (Table 1, bottom panel).

Table 2 provides a summary for each product variety and income group by multiplying a 1-standard deviation increase of the variety growth with its coefficient estimates from the GMM dynamic panel estimation (using 5-year average variety growth; Table 1, bottom panel). The conflict-reducing gains from variety growth are larger for the low-income countries (8.4-10.5\%) in comparison to the gains for the middle-income countries (3.7-5.1\%). Further, the gains are larger on the internal conflicts, ${ }^{3}$ and have a similar size across the Rauch's product classification.

\section{Related studies and limitations}

These new findings of the conflict-reducing gains from trade variety cut across at least two strands of the literature. The first strand studies potential welfare gains from international trade through the import of new varieties. Broda and Weinstein (2004) find that the U.S. consumers gain from increased import variety via the varietyadjusted import price reduction. The second strand examines whether globalization offers an extra benefits by pacifying international relations. Martin et al. (2008) find that regional and bilateral trade agreements decrease the probability of wars and thus have some positive consequences for political relations. This paper adds to the literature by providing the evidence that larger variety - the extensive margin - of international trade is also associated with lower political conflicts. Excluding exports would bias downward the effects of variety growth. ${ }^{4}$ Yet, the analysis is only half of the story: future studies delve further into the role of quality, survival and deepening of trade relationship along the lines of Besedes and Prusa (2007) and Hummels and Klenow (2005) will be useful.
Two limitations are in order. First, there may be a reverse causality from political conflict to trade variety. ${ }^{5}$ Using two cross-country survey data sets, Mayda and Rodrik (2005) find that nationalism and the lower level of human capital are associated with protectionist tendencies. Dutt and Mitra (2005) also find that government ideology may affect trade policy, with the right-wing tends to adopt more protectionist in labor-rich countries, than the right-wing. Second, the paper does not pertain to control for all possible common factors driving simultaneously political conflict and variety growth, i.e. the diversity of population (Grossman and Maggi, 2000), the quality of institutions (Nunn, 2007), the role of immigration and business networks (Moenius et al., 2007). The main findings of this paper also suggest that it would be useful to extend the analysis into the mechanism behind the relationship between the extensive margin and the risk of conflicts. For example, the empirical framework in this paper can be readily extended to test whether the extensive margin still affects the probability of conflict, after controlling for trade openness and regional trade agreements. ${ }^{6}$

\section{References}

Antràs, P., Staiger, R.W., 2008. Offshoring and the role of trade agreements. NBER Working Paper No. 14285.

Arellano, M., Bond, S., 1991. Some tests of specification for panel data: Monte Carlo evidence and an application to employment equations. Review of Economic Studies 58, 277-297.

Besedes, T., Prusa, T.J., 2007. The role of extensive and intensive margins and export growth. NBER Working Papers No. 13628.

Blomberg, S.B., Hess, G.D., 2006. How Much Does Violence Tax Trade? Review of Economics and Statistics 88, no. 4: 599-612.

Broda, C., Weinstein, D.E., 2004. Variety growth and world welfare. American Economic Review 94, 139-144.

Dutt, P., Mitra, D., 2005. Political ideology and endogenous trade policy: an empirical investigation. Review of Economics and Statistics 87, 59-72.

Economist, 2008. Somewhere over the rainbow. January 24th.

Glick, R., Taylor, A.M., 2006. Collateral damage: trade disruption and the economic impact of war. NBER Working Papers No. 11565.

Grossman, G.M., Maggi, G., 2000. Diversity and trade. American Economic Review 90 $1255-1275$.

Hummels, D., Klenow, P.J., 2005. The Variety and Quality of a Nation's Exports. American Economic Review 95, no. 3: 704-23.

Judson, R.A., Owen, A.L., 1999. Estimating dynamic panel data models: a guide for macroeconomists. Economics Letters 65, 9-15.

Martin, P., Mayer, T., Thoenig, M., 2008. Make Trade not War? Review of Economic Studies 75, no. 3: 865-900.

Mayda, A.M., Rodrik, D., 2005. Why are some people (and countries) more protectionist than others? European Economic Review 49, 1393-1430.

Moenius, J., Rauch, J.E., Trindade, V., 2007. Gravity and matching. University of California, San Diego.

Nunn, N., 2007. Relationship-specificity, incomplete contracts, and the pattern of trade. Quarterly Journal of Economics 122, 569-600.

Rauch, J.E., 1999. Networks versus markets in international trade. Journal of International Economics 48, 7-35.

\footnotetext{
${ }^{3}$ The correlation between the internal and the external conflicts is .58 .

4 The import statistics tend to be more accurate than the export due to its necessity for tariff collection. However, the significance of re-exports in some countries for entrepôt trade may complicate the measurement.
}

\footnotetext{
${ }^{5}$ For the effects of war and violence on trade, see Blomberg and Hess (2006) and Glick and Taylor (2006).

${ }^{6}$ See for example Antràs and Staiger (2008) on the impact of the rise of offshoring of intermediate inputs on global policy cooperation and international trade agreements.
} 